\title{
Role of laboratory chemosensitivity testing in the selection of cancer chemotherapy for individual patients
}

\section{PJ SELBY,* D RAGHAVAN $\dagger$}

From the *Divisions of Medicine, Biophysics, and Radiotherapy, Institute of Cancer Research, Belmont, Surrey, and the $\dagger$ Unit of Human Cancer Biology, Ludwig Institute for Cancer Research, The Royal Marsden Hospital, Belmont, Surrey

SUMMARY Recently several assays have been developed which allow the growth of colonies from cell suspensions prepared from human tumour biopsy specimens. It has been suggested that such assays will provide a reliable means of measuring the chemosensitivity of human tumours for predicting the response to treatment in patients. We have briefly reviewed the previous, largely unsuccessful, attempts at chemosensitivity testing and the potential place of the new assays. The measurement of the survival of clonogenic tumour cells after cytotoxic treatment probably reflects to some extent the survival of cells which in vivo are capable of proliferating to repopulate and regrow the tumour. This endpoint therefore has advantages over alternatives that do not directly measure reproductive cell death, and the assays also have the advantage of suppressing the growth of many non-malignant cells found in tumours. However, technical problems such as the preparation of cell suspensions and the artificial nature of the drug exposure phase of the assays have not been completely overcome and the plating efficiencies remain low in most systems. Work with model systems such as human tumour xenografts tends to support the usefulness of the assays but also highlights some difficulties. Clinical studies of chemosensitivity testing are in progress and initial results are encouraging but inconclusive.

The suggestion that laboratory tests performed with drugs directly on a patient's tumour might lead to the selection of appropriate cancer therapy for that patient has been made for many years. ${ }^{1}$ It has drawn support from the analogy to infectious diseases where laboratory microbiological sensitivity tests have a major impact on clinical practice. However, the results of numerous attempts to develop a variety of different tests suitable for human cancers have been disappointing. Recently, assays have become available for the growth of colonies from cell suspensions of human tumour cells, ${ }^{2-5}$ and it has been suggested that these may form the basis of a new generation of chemosensitivity tests for human tumours. ${ }^{56}$ In this paper we present a brief review of the background to these studies and examine the potential and limitations of the clonogenic cell assays as predictive chemosensitivity tests.
The rationale of chemosensitivity tests on individual human tumours

Histopathological study divides human neoplasms into groupings which are of great importance in predicting response to chemotherapy. The striking contrast in the sensitivity of, for instance, Hodgkin's disease and malignant melanoma is well known. More detailed study using histochemical, immunological, and biochemical analysis of tumours of similar morphology can add considerably more information about the likely outcome of therapy. A chemosensitivity test on an individual tumour should define its place within a group of tumours which are histologically similar but heterogeneous in sensitivity. It is, therefore, complementary to knowledge derived from clinical studies of the overall response pattern of the group. The value of such a test must, therefore, be related to the degree of heterogeneity in sensitivity that exists to an agent within a group of 
tumours which are not otherwise distinguishable. Clinical experience certainly suggests that substantial heterogeneity exists within many groups of tumours when they are treated with currently available agents: some patients respond while others do not. However, variations in drug pharmacokinetics and metabolism may be responsible for substantial differences between patients, and additional direct evidence that the tumours themselves are heterogeneous is necessary. Human tumours grown as xenografts in immune-deprived mice have proved useful experimental systems for the study of heterogeneity within tumour types, and a substantial body of evidence for its existence has emerged. ${ }^{7-9}$ An example of this kind of study is shown in Fig. 1, in which cell survival curves for three different melanoma xenografts treated with methyl CCNU are compared to a similar curve for normal human bone marrow. A wide range of chemosensitivity is demonstrated, and the melanomas may be more resistant to this drug than is normal marrow, or considerably more sensitive.

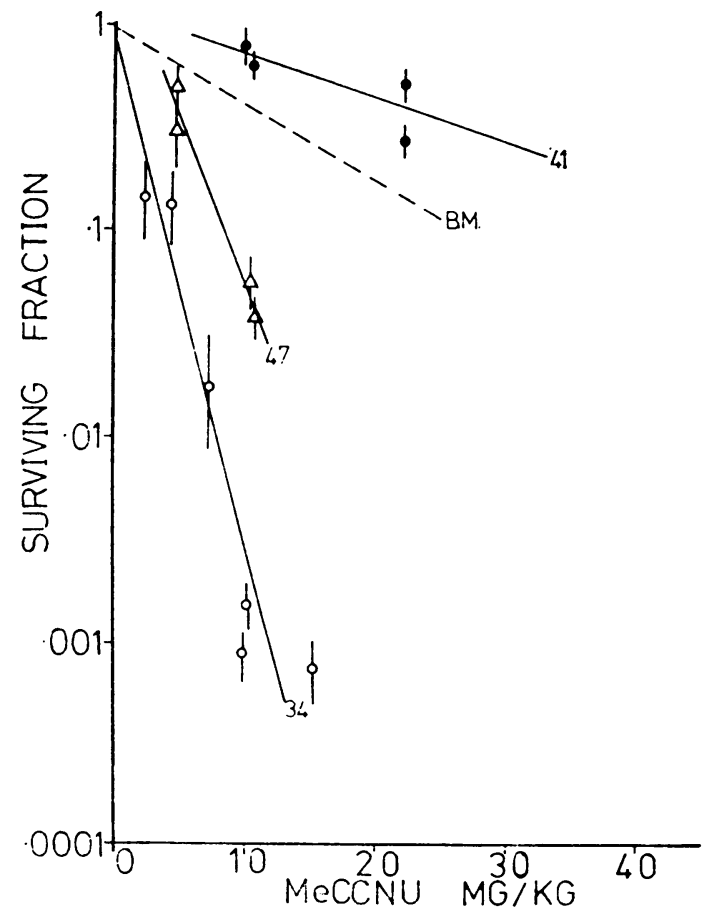

Fig. 1 Clonogenic cell survival after treatment in agar diffusion chambers with methyl CCNU of normal human bone marrow cells $(B M)$ and three different melanoma xenograft lines, $41(\bigcirc), 47(\triangle)$, and $34(\bigcirc)$. From Selby et al. ${ }^{10}$
Attempts to develop direct chemosensitivity tests $\stackrel{\overrightarrow{5}}{\overrightarrow{0}}$ have shown a range of responses for histologically similar tumours, which also suggests the existence of? heterogeneity. ${ }^{6} 11$

If we accept the evidence that heterogeneity of들 response exists within tumour types, a chemo- $-\overline{\frac{p}{5}}$ sensitivity test is likely to be of value only if the pattern of this heterogeneity varies between drugs. Ifes a tumour which is resistant to one drug tends also tobe resistant to others, then a study of the tumour in $a$ test employing a range of drugs will give no more $\vec{\omega}$ information than a single test (clinical or laboratory) with one drug. In clinical practice, this question? presents as the problem of 'cross-resistance', and itw has been shown that while cross-resistance mayer occur, it is by no means invariable. For example patients with multiple myelomas who have ceased to respond to one alkylating agent may respond to another. ${ }^{12}$ Laboratory data which bear on this question for human tumours are limited, but studies in xenografted tumours may again be helpful. Analyses of the response patterns of groups of $\overrightarrow{0}$ melanoma and colonic carcinoma xenografts haveindicated that, while some tumours may appear to beg generally more resistant to all of a series of drugs, this tendency is not consistent. ${ }^{7913}$

It is known that there may be variation in chemo sensitivity between different parts of a tumour. For instance, in the treatment of testicular teratoma, the response of subpopulations producing one serum marker may be observed concurrently with nonresponse in a subpopulation producing a differento marker. ${ }^{14}$ This may lead to 'sampling errors' in chemosensitivity test.

The clinical impact of a chemosensitivity test willo depend also upon the overall responsiveness of the type of tumour to treatment. The therapy of aO tumour with an almost $100 \%$ response rate and $a$ high cure rate with conventional treatment will bes little affected by a predictive test, no matter how $>$ accurate. Similarly, a completely resistant type of tumour will prove lethal even if treated with the bestr of several bad options. Consideration of these factors is important not only in assessing the likely value of tests but also in assessing the likelihood of detectingw clinical impact in a trial of chemosensitivity testing? A negative or statistically unconvincing result in sucho a trial may reflect the current state of chemotherapy rather than the validity of the test employed.

\section{Methods of chemosensitivity testing}

Some examples of the numerous reported attempts to® establish chemosensitivity tests have been set out ing the Table. ${ }^{611} 15-24 \mathrm{~A}$ wide range of methods have been employed, and varying degrees of clinicato 
In-vitro chemosensitivity tests measuring cell damage or death

\begin{tabular}{|c|c|c|c|}
\hline \multicolumn{2}{|c|}{ Preparation of material } & Endpoint of assay & Reference \\
\hline \multicolumn{2}{|c|}{ Tissue explant } & \multirow{3}{*}{$\begin{array}{l}{ }^{32} \mathrm{p} \text { orthophosphate incorporation } \\
{ }^{3} \mathrm{H} \text { thymidine incorporation and enzyme activity } \\
\text { Enzyme activity }\end{array}$} & \multirow{3}{*}{$\begin{array}{l}\text { Tchao }(1967)^{15} \\
\text { Knock }(1974)^{16} \\
\text { Di Paolo }(1963)^{17}\end{array}$} \\
\hline , & , & & \\
\hline , & ", & & \\
\hline \multicolumn{2}{|c|}{ Cell suspensions } & \multirow{2}{*}{$\begin{array}{l}\text { Cell counts } \\
\text { Cell morphology }\end{array}$} & \multirow{8}{*}{$\begin{array}{l}\text { Holmes }(1974)^{18} \\
\text { Wright }(1975)^{10} \\
\text { Limberg }(1968)^{20} \\
\text { Tanneberger }(1968)^{21} \\
\text { Dendy }(1980)^{11} \\
\text { Freshney }(1975)^{22} \\
\text { Gordon }(1977)^{23} \\
\text { Rosenblum }(1980)^{24} \\
\text { Salmon }(1978)^{8}\end{array}$} \\
\hline \multirow[t]{3}{*}{ ", } & \multirow[t]{3}{*}{ ", } & & \\
\hline & & ", $\quad$ " & \\
\hline & & ${ }^{125}$ I deoxyuridine incorporation & \\
\hline$"$ & $"$ & ${ }^{\mathbf{3}} \mathrm{H}$ leucine incorporation & \\
\hline " & , & Colony formation in chronic myeloid leukaemia & \\
\hline ", & $"$ & Colony formation in brain tumours & \\
\hline$"$, & , & Colony formation in various tumours & \\
\hline
\end{tabular}

correlation have been sought and claimed. However, certain themes and problems are common to most methods:

PREPARATION OF MATERIAL FOR TESTING This most commonly involves the preparation of a single cell suspension from solid tumours or the use of cultured tumour explants. Explants have the advantage that tissue trauma is minimised and cellular interrelationships are maintained. However, they may be difficult to quantify and contain substantial numbers of non-tumour cells which may influence the results.

The preparation of single-cell suspensions is a major technical problem. Most workers employ mechanical disaggregation of tumours, and may follow this by enzymatic digestion with trypsin ${ }^{25}$ or collagenase. ${ }^{26}$ These methods may fail to yield sufficient viable cells for testing, particularly from tumours containing large quantities of fibrous tissue. ${ }^{5}$ However, other workers have found no difficulty in obtaining large numbers of single cells by mechanical methods alone. ${ }^{27}$ If a suspension can be obtained, cell damage or modification may have occurred, and this may lead to failure of the test or an erroneous result. In experimental murine tumours, suspension techniques may alter the apparent chemosensitivity of a tumour. ${ }^{28} 29$

\section{CONFIRMATION OF TUMOUR CELL}

PREPONDERANCE IN THE TEST POPULATION

A tumour biopsy, sample of effusion, or infiltrated bone marrow contain substantial numbers of nonmalignant cells derived from stroma and normal tissue. These may represent a potent source of error. There are three general approaches to this difficulty. Firstly, identification of tumour cells may be attempted and cultures containing an excess of nontumour cells excluded. Cell morphology and growth pattern are widely used to identify malignant cells but are unreliable. ${ }^{30}$ More reliable indicators of malignant cells are karyotype, ${ }^{31}$ DNA content, ${ }^{11}$ or tumour specific marker substances, such as $\alpha$ fetoprotein, chorionic gonadotrophins, or carcinoembryonic antigen. The use of monoclonal antisera to tumour cells may prove a valuable advance in this field. Alternatively, separation of tumour cells has been attempted using variation in sedimentation velocity and density, ${ }^{32} 33$ but tumour cells may have physical properties similar to those of normal cells, and separation on this basis seems unlikely to be universally successful. Finally, growth systems which offer selective advantage to tumour cells have been devised, such as fibroblast inhibition by cis-hydroxyproline. ${ }^{34}$ The selectivity of semisolid medium for tumour cell growth may be one of the greatest advantages of assays based on colony growth (see below).

\section{EXPOSURE CONDITIONS}

The drug exposure phases of chemosensitivity tests are usually artificial, involving the separation of cells from stroma and the disturbance of cell-to-cell relationships. Considerable attention has been paid to the importance of the proliferation kinetics of cells under test, and there is little doubt that this influences chemosensitivity. ${ }^{35}$ However, it is only one determinant of sensitivity and perhaps not always the most important. The changes in kinetics that are likely to occur when cell suspensions are prepared 2829 may not, therefore, necessarily invalidate the tests performed.

\section{CHOICE OF DRUG CONCENTRATION AND} DURATION

The peak plasma concentration and elimination half-lives of anti-cancer drugs vary tremendously, and many drugs require metabolic activation. Dosages may vary between protocols and patients. For agents with cycle-phase specificity, ${ }^{36}$ such as cytosine arabinoside or methotrexate, the duration of exposure is critical in determining therapeutic effect 
and patient toxicity. The penetration of drugs into tumours varies between drugs and with tumour size, ${ }^{37}$ and the peak concentrations and elimination half-lives of drugs in tumours are frequently unknown.

Simulation of in vivo drug exposure seems, therefore, to be a difficult objective, and many investigators have fallen back on the assumption that drug doses dissolve in total body water to calculate in vitro exposure concentrations. ${ }^{1838}$ Bateman et $a l .{ }^{1339}$ looked at the usefulness of both peak in vivo plasma levels and a value derived from estimation of the product of drug concentration $\times$ clearance time in the development of a predictive in vitro test. They found that in vitro cell survival at both of these values could be used to predict in vivo response of a series of human tumour xenografts.

Salmon and his co-workers ${ }^{60}$ have employed a pragmatic approach to the problem of selection of drug concentration and the prediction of patient response. Tumour cells are exposed to a range of drug concentrations which span the approximate expected in vivo concentration. The measure of in vitro response is taken as the area under a doseresponse curve up to a maximum dose chosen to relate to in vivo concentrations. The value of the area under the curve which suggests 'sensitivity' or 'resistance' is determined by reference to a retrospective series of patients who were treated with the drug under test for the tumour in question. Discrimination between response and non-response by this method is not perfect but it is significant in their hands. The concept inherent in this approach-that in vitro simulation of pharmacokinetics will require validation against a reference 'panel' of patients studied-will probably be essential in the development of successful chemosensitivity tests.

\section{CHOICE OF ENDPOINT}

Selection of a suitable laboratory endpoint which relates to clinical tumour regression or cure has proved difficult. An ideal test for widespread application should be cheap, easy, reproducible, and likely to reflect the death of those cells within a tumour which are responsible for its continued growth and for repopulation after treatment, that is, tumour stem cells.

The endpoints that have been employed may be grouped as follows:

\section{(a) Indirect tests}

Cells are assayed for a biochemical or structural feature necessary to the action of the drug under test. This most commonly involves measurement of drug uptake, metabolism, or the presence of drug receptors. For instance, lack of methotrexate retention by whole leukaemic cells after short incubations with radiolabelled drug has been shown to predict lack of clinical response in a variety of leukaemias, ${ }^{41}$ and similar results have been claimed for nucleotides of 6-mercaptopurine and cytosine arabinoside. ${ }^{42}$ However, not all leukaemic blasts which retain drugs are sensitive, demonstrating that drug uptake is a necessary but not a sufficient feature for drug sensitivity. Similar arguments apply to tests for the presence of drug receptors. Correlations have been reported between clinical response to steroids and the presence of steroid receptors in non-Hodgkin lymphomas, ${ }^{43}$ and chronic lymphocytic leukaemia, ${ }^{44} 45$ and between duration of remission on combination therapy and steroid receptors in acute lymphoblastic leukaemia. ${ }^{46}$ However, it is clear from experimental studies that cells may bear steroid receptors but be unresponsive to treatment, ${ }^{47}$ which again suggests that receptors are a necessary but not sufficient feature for clinical response. Similar data are available for oestrogen receptors in breast cancer where tumours which lack receptors rarely respond to endocrine manipulation while those which have them do not always do so. ${ }^{48}$ It seems, therefore, that such indirect endpoints may be valuable in predicting clinical resistance to the therapy tested but are unlikely to predict sensitivity consistently.

\section{(b) Tests for cell damage or cell death}

The methods most widely used to estimate cell death after treatment have been morphological change in cells, reduction in cell counts after culture, reduced ability to exclude vital dyes, loss of radiolabel from lysed cells, reduction in incorporation of radiolabelled macromolecule precursors, reduction in enzyme activity within tumours, and, most recently, direct measurement of reproductive cell death by colony inhibition.

The lethal effect of a cytotoxic agent upon a cell is determined by the severity and duration of damage caused to critical targets and the cell's ability to repair this damage. It is known that lethally damaged cells may complete DNA synthesis and even undergo one or more divisions before finally dying out ('doomed cells'). On the other hand, cells that have received substantial metabolic insults may recover and divide normally. ${ }^{49}$ It seems unlikely that measurements of the biochemical activity of cells or of short-term changes in cell number would reflect accurately damage to the stem cell compartment. In fact the lack of correlation of biochemical, cell number, dye exclusion, and morphological endpoints with reproductive cell death has been demonstrated by several groups using model systems. ${ }^{50-53}$ There is, therefore, a sound theoretical basis and a substantial body of experimental data which lead to the suggestion 
that the direct measurement of reproductive cell death, as proposed for a clonogenic cell survival assay, may represent the most valid endpoint for a chemosensitivity test.

\section{Clonogenic cell survival assays}

Colony-forming cell assays have been available for human monolayer cell lines, human and rodent bone marrow cells, and experimental animal tumours for several decades. ${ }^{54-56}$ Until recently, however, only a few attempts had been made to grow colonies directly from human tumours, and these met with limited success. ${ }^{5758}$ The availability of human tumour xenografts was used by some workers as a source of material for the development of cloning assays in semisolid media for human tumour cell in vitro $^{459}$ and in intraperitoneal diffusion chambers in mice. ${ }^{2}$ These techniques have subsequently proved to be applicable to human tumours taken directly from patients. ${ }^{5}$ Hamburger, Salmon, and their co-workers at the University of Arizona developed assays employing semisolid agar or methyl cellulose with enriched media and reported successful colony growth from myeloma cells from bone marrow, ovarian carcinoma ascites, ${ }^{3}$ ovarian carcinoma, ${ }^{27}$ lymphoma, ${ }^{60}$ bladder carcinoma, ${ }^{61}$ colonic carcinoma, ${ }^{62}$ and melanoma. ${ }^{63}$ Buick et al. ${ }^{64}$ reported growth of colonies of leukaemic myeloblasts using a medium enriched by incubation of normal leucocytes with phytohaemagglutinin. Some tumour types, including primary colonic carcinoma or head-andneck tumours, have proved difficult to clone. ${ }^{74}$

These assays have in common the plating of cell suspensions in a semisolid medium such as soft agar $(0 \cdot 2-0.5 \%$ agar dilutions) and the provision of an enriched and/or conditioned feeding medium which may be periodically renewed. The proportion of plated cells which forms colonies is low in all of the systems, often considerably less than $1 \%$. Whether these low plating efficiencies reflect inadequate culture conditions or a low proportion of stem cells within human tumours remains unclear. Colony growth proceeds over a period of two to three weeks in most assays. Although the complexity of the assays is variable, all are technically demanding, involving careful cell counting and plating, rigid sterile precautions under laminar flow hoods, prolonged incubation under controlled, sterile conditions, and tedious and painstaking counting of colonies. Material and media are relatively expensive, and the 'semi-in vitro agar' diffusion chamber technique is very expensive of mice. Methods do not readily lend themselves to automation although some attempts at automated counting are being made. Present methods are not technically or logistically within the range of a routine hospital laboratory.

The ability to form colonies in semisolid media is regarded as a characteristic of malignant cells, and stromal cells which attach to culture dishes and grow as monolayers are unable to form colonies. ${ }^{65} \mathrm{How}$ ever, colony formation is also a feature of haemopoietic precursor cells, stimulated lymphocytes, and macrophage precursor cells. ${ }^{66} 67$ Recently, it has been shown that experimental murine tumours may contain clonogenic macrophage precursor cells, ${ }^{68}$ which may also be present in human xenografts. ${ }^{9}$ Despite these other sources of clonogenic cells, the selectivity of cloning assays in soft media for tumour cells is one of their major advantages as putative chemosensitivity tests.

The low plating efficiencies obtained in most cloning assays when tumours are taken directly from patients may reflect the potential of the systems to select for subpopulations of cells. The results of chemosensitivity tests on these subpopulations could bemisleading. The likelihood that this is an important flaw in the assays is reduced by the observation that similar results are obtained when colonies are grown under widely differing culture conditions in soft agar or as lung colonies in immune-deficient mice. ${ }^{69}$ It is also reassuring that the chemosensitivity of tumour cells taken directly from a patient and tested in a cloning assay was similar to that of the human tumour xenograft, derived from the same biopsy, which grew with a higher plating efficiency ${ }^{70}$ (see Fig. 2). These studies provide some support to the hypothesis that cloning assays with low plating efficiencies may be representative of a tumour as a whole.

Two groups have used model systems to study the value of in vitro chemosensitivity assays based on cell cloning. An in vitro test was shown to predict the response of a murine experimental myeloma in vivo. ${ }^{71}$ More recently, in vitro tests have been used to predict the in vivo response of human tumour xenografts. The in vitro sensitivity of cells of a human pancreatic carcinoma xenograft to a range of drugs correlated well with their sensitivity in the mouse. ${ }^{39}$ However, in a later series of experiments using a series of melanoma xenografts the situation was less clear $^{13}$ (Fig. 3). Surviving fractions in the in vitro test correlated significantly with those in vivo for some drugs, and the in vitro test was able to predict which tumour would be most sensitive to a particular drug. However, the in vitro test did not reliably predict which drug would be most effective in vivo for a particular tumour, and it was notable that adriamycin was ineffective in vivo while achieving substantial cell kill in vitro. These failures probably reflected the difficulty in relating murine in vivo drug levels to the in vitro exposure concentrations (derived from human concentration $\times$ time data). They highlight 


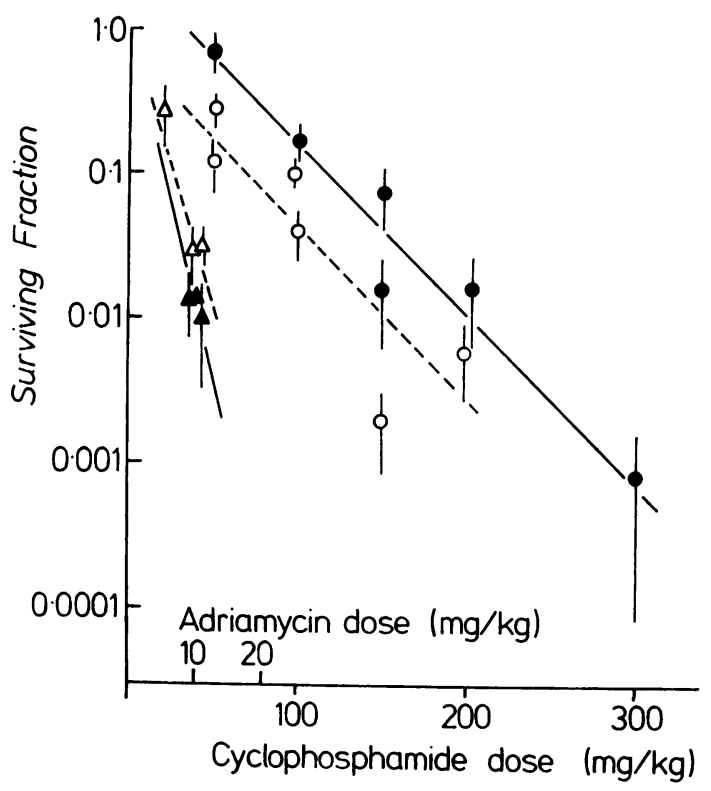

Fig. 2 Clonogenic cell survival after treatment of human tumour cell suspensions prepared directly from cryopreserved tumour biopsies or from xenograft line derived from the same biopsies. Cyclophosphamide treatment of directly prepared cells $(\bigcirc)$ and xenograft cells $(\bigcirc)$; adriamycin treatment of directly prepared cells $(\triangle)$ and xenograft cells $(\Delta)$. From Selby and Steel. ${ }^{70}$

the general case that pharmacological uncertainties make it far more difficult to compare results for one tumour with different drugs than to compare different tumours treated with the same drug.

Our knowledge of the theoretical and experimental basis of clonogenic cell survival assays suggests, therefore, that they have the advantages of selectivity for tumour cells and a direct relationship between colony growth and cellular reproductive capacity. However, their drawbacks include the difficulties of preparing cell suspensions, pharmacokinetic uncertainties, and the low plating efficiencies obtained.

\section{Clinical correlations}

Demonstration of a significant impact of a test upon clinical results will remain necessary no matter how theoretically attractive it may be. Many workers have claimed clinical correlation for their tests (for example, ${ }^{20} 721619$ ). However, numbers of patients studied are generally small, and the results are therefore difficult to assess. Dendy and co-workers ${ }^{11}$ have accumulated a substantial body of data using an in vitro assay based initially upon morphological changes in

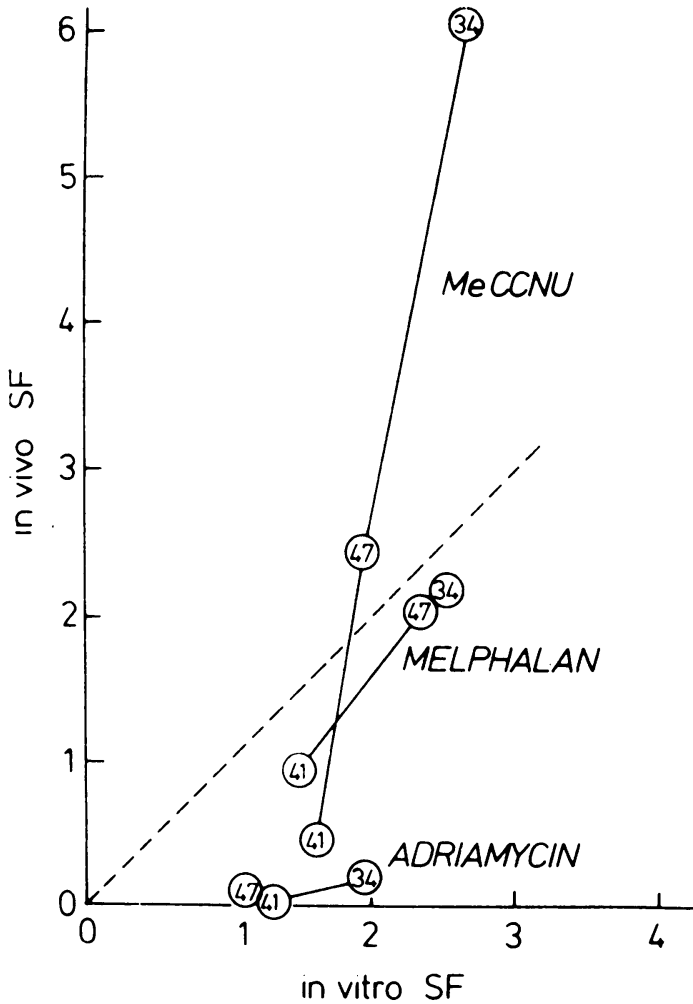

Fig. 3 Relationship between cell survival (expressed as negative $\log _{10}$ surviving fractions) in human melanoma xenografts treated either as solid tumours growing in mice (in vivo $S F$ ) or as cell suspensions in vitro (in vitro $S F$ ). Each circled number represents the data for one xenograft treated with one drug in these two situations.

The broken line represents the ideal situation where in vitro results reflect in vivo results precisely. The surviving fractions in vivo are those at an $L D_{10}$ dose of drug, whereas those in vitro relate to levels achievable in man.

For melphalan the data lie quite close to the theoretical ideal line. For adriamycin, in vitro cell kill greatly exceeded in vivo cell kill. For methyl CCNU the comparison varied between different tumour lines. From Bateman et al. ${ }^{13}$

cells after treatment and, more recently, upon inhibition of incorporation of ${ }^{125}$ IUdr. They have worked mainly with advanced ovarian carcinoma patients, and a comparison between the results of treatment based upon their test and treatment not so based suggested an initial benefit from the test.

The theoretical advantages of clonogenic cell survival assays might lead us to expect even greater benefit from their application to clinical cases. Initial reports from Salmon's group have been encourag- 
ing. ${ }^{640}$ Their first report ${ }^{6}$ described 32 comparisons between in vitro test results and clinical response in 18 patients with myeloma and ovarian carcinoma. The results were highly significantly correlated $(p<0.00001)$ and there was substantial heterogeneity within the two groups of patients. Closer examination of the data reveals that the excellence of the statistical values is largely a reflection of the overall resistance of ovarian carcinoma and the overall sensitivity of myeloma to alkylating agents. However, sufficient heterogeneity existed within the groups to suggest that the test may be revealing some individual tumour characteristics. Follow-up reports suggest that the assay remains reliable in predicting chemoresistance but rather less so for chemosensitivity. A prospective study is in progress to assess the impact of the test in their ovarian carcinoma patients, and initial results are encouraging. ${ }^{40}$

Other clinical studies assessing cloning assays are as yet few. Rosenblum et al. ${ }^{24}$ have reported encour. aging results with an assay applied to high-grade astrocytomas, and anecdotal results are available comparing clonogeneic cell survival in xenografts of human melanomas with clinical response. ${ }^{9}$ However, widespread application of cell survival assays must await convincing clinical trials conforming to acceptable standards of study design, performed in a large number of patients and preferably proving successful in the hands of independent groups of workers.

\section{Human tumour xenografts}

We have concentrated on the uses of in vitro assay systems as laboratory chemosensitivity tests, reflecting the extent of the data available in the literature. However, human tumours grown as xenografts in immune-suppressed mice have been widely used in the development and assessment of some of these tests, and there is evidence that such tumours may maintain the pattern of chemosensitivity of their tumoursof-origin. ${ }^{70} 73$

It has been suggested that such tumours could form the basis of a direct chemosensitivity test designed to predict response in the individual patient. ${ }^{75}$ However, preliminary data have suggested that such a system is not likely to be of practical use. ${ }^{76}$ In a cumulative assessment of their experience in xenografting tumours of the breast, lung, and ovary, and malignant teratomas and melanomas, Bailey et al. have demonstrated that the low overall 'take' rates and lengthy delays before the initial establishment of transplantable xenograft lines (the 'lag phase') appear to preclude the routine use of such a system. Furthermore, the high cost of the animals expended in a test system with a relatively low yield was another problem encountered. Finally, those patients with tumours that had higher 'take' rates appeared to have a shorter survival after the time of xenografting, which, in combination with the initial lag phase, limited the use of the test.

\section{Conclusions}

In this paper we have emphasised the considerable technical difficulties involved in attempts to develop a suitable laboratory system for predictive chemosensitivity testing. The recently developed clonogenic cell assays have theoretical and practical advantages, but they are technically demanding and do not overcome all of the problems. Initial clinical results appear to be encouraging, but only the prediction of drug resistance is reliable. While this may spare some patients unnecessary and unhelpful chemotherapy, it is unlikely to improve their prognosis greatly. Chemotherapy of common tumours is still ineffective and toxic. The use of reliable chemosensitivity tests may improve the results somewhat and may serve to increase the benefits from new and more effective agents.

\section{References}

${ }^{1}$ Wright JC, Cobb JP, Gumport SL, Golomb FM, Safadi D. Investigation of the relation between clinical and tissue culture response to chemotherapeutic agents on human cancer. $N$ Engl J Med 1957;257:1207.

${ }^{2}$ Smith IE, Courtenay VD, Gordon MY. A colony forming assay for human tumour xenografts using agar in diffusion chambers. Br J Cancer 1976;34:476.

${ }^{3}$ Hamburger AW, Salmon SE. Primary bioassay of human tumour stem cells. Science 1977;197:461.

${ }^{4}$ Courtenay VD, Mills J. An in vitro colony assay for human tumours grown in immune-suppressed mice and treated in vivo with cytotoxic agents. Br J Cancer 1978; 37:261.

${ }^{5}$ Courtenay VD, Selby PJ, Smith IE, Mills J, Peckham MJ. Growth of human tumour cell colonies from biopsies using two soft agar techniques. Br J Cancer 1978;38:77.

- Salmon SE, Hamburger AN, Soehnlen BS, Durie BGM, Alberts DS, Moon TE. Quantitation of differential sensitivity of human tumour stem cells to anti-cancer drugs. N Engl J Med 1978;298:1321.

7 Nowak K, Peckham MJ, Steel GG. Variation in response of xenografts of colorectal carcinoma to chemotherapy. Br J Cancer 1978;37:576.

8 Osieka R, Houchens DP, Goldin A, Johnson RK. Chemotherapy of human colon cancer xenografts in athymic nude mice. Cancer 1977;40:2640.

- Selby PJ, Courtenay VD, McElwain TJ, Peckham MJ, Steel GG. Colony growth and clonogenic cell survival in human melanoma xenografts treated with chemotherapy. Br J Cancer $1980 ; 42: 438$.

${ }^{10}$ Selby PJ, Smith IE, Gordon MY. Growth of colonies of human bone marrow and tumour cells in soft agar in diffusion chambers. In: Diffusion chamber culture. Cronkite EP, Carsten AL, eds. Berlin, Heidelberg, New York: Springer-Verlag, 1980:175.

${ }^{11}$ Dendy PP. The use of in vitro methods to predict tumour 
response to chemotherapy. $B r J$ Cancer 1980;41 (Suppl. IV):195.

12 Bergsagel DE, Cowan DH, Hasselback R. Plasma cell myeloma: response of melphalan-resistent patients to high-dose intermittent cyclophosphamide. Can Med Assoc J 1972;107:851.

${ }^{13}$ Bateman AE, Selby PJ, Steel GG, Towse GD. In vitro chemosensitivity tests on xenografted human melanomas. Br J Cancer 1980;41:189.

${ }^{14}$ Raghavan D, Gibbs J, Nogueira Costa R, Kohn J, Orr AH, Barrett A, Peckham MJ. The interpretation of marker protein assays: a critical appraisal in clinical studies and a xenograft model. Br J Cancer 1980;41 (Suppl. IV):191.

15 Tchao R, Eastey DW, Ambrose EJ. The use of 32plabelled orthophosphate for the assay of chemotherapeutic agents on tumours maintained in organ culture. Br J Cancer 1967;21:821.

${ }^{16}$ Knock FE, Galt RM, Oester T, Sylvester R. In vitro estimate of sensitivity of individual human tumours to anti-tumour agents. Oncology 1974;30:1.

${ }^{17} \mathrm{Di}$ Paolo JA. In vitro test systems for cancer chemotherapy. Cancer Res 1963;23:184.

${ }^{18}$ Holmes HL, Little JL. Tissue culture microtest for predicting response of a human cancer to chemotherapy. Lancet 1974 ;ii:985.

19 Wright JC, Walker D. A predictive test for the selection of cancer chemotherapeutic agents for the treatment of human cancer. $J$ Surg Oncol 1975; 7:381.

${ }^{20}$ Limberg H, Heckman U. Chemotherapy in the treatment of advanced pelvic malignant disease with special reference to ovarian cancer. J Obstet, Gynaec, $\mathrm{Br}$ Commonwlth 1968;75:1246.

${ }^{21}$ Tanneberger S, Bacigalupo G. Die benutzung von Zellkulturen zur ermittlung der sensibilitat menschlicher tumoren gegenuber zytostatika. Deutsche Gesundheitswesen 1967;22:11.

${ }^{22}$ Freshney RI, Paul J, Kane IM. Assay of anti-cancer drugs in tissue culture: conditions affecting their ability to incorporate $3 \mathrm{H}$-leucine after drug treatment. Br J Cancer 1975;31:89.

${ }^{23}$ Gordon MY, Douglas IDC. The effects of busulphan, hydroxyurea and cytosine arabinoside on the colony forming cells in chronic granulocytic leukaemic and nonleukaemic marrow. Leukaemia Res 1977;1:71.

${ }^{24}$ Rosenblum ML, Dougherty DS, Deen DF, Hoshino T, Wilson CB. Analysis of clonogenic human brain tumour cells: preliminary results of tumour sensitivity testing with BCNU. BrJ Cancer 1980;41(Suppl. IV):181.

${ }^{25}$ Madden RE, Burk D. Production of variable single cell suspensions from solid tumours. J Natl Cancer Inst $1961 ; 27: 841$.

${ }^{26}$ Freshney RI. Tumour cells disaggregated in collagenase. Lancet $1972 ;$ ii:488.

${ }^{27}$ Hamburger AW, Salmon SE, Kim MB, et al. Direct cloning of human ovarian carcinoma cells in agar. Cancer Res $1978 ; 38: 3438$.

${ }^{28}$ Barendson GW. Analysis of tumour response by excision and in vitro assay of cellular clonogenic capacity. $\mathrm{Br} J$ Cancer 1980;41 (Suppl. IV):209.

29 Rasey JS, Nelson NJ. Response of an in vivo-in vitro tumour to X-rays and cytotoxic drugs: effect of tumour disaggregation method on cell survival. $B r J$ Cancer 1980;41(Suppl. IV):217.

${ }^{30}$ Billiau A, Cassiman JJ, Willems D, Verhelst M, Heremans $H$. In vitro cultivation of human tumour tissues. Oncology $1975 ; 31: 257$.

${ }^{31}$ Guner M, Freshney RI, Morgan D, Freshney MG, Thomas DGT, Graham DI. Effects of dexamethasone and betamethasone on in vitro cultures from human astrocytomas. Br J Cancer 1977;35:439.

${ }^{32}$ Boone CW, Harrell GS, Bond HE. The resolution of mixtures of viable cells into homogeneous fractions by zonal centrifugation. J Cell Biol 1968;36:369.

${ }^{33}$ Sykes JA, Whitescarver J, Briggs L, Anson JH. Separation of tumour cells from fibroblasts with use of discontinuous density gradients. J Natl Can Inst 1970;44:855.

${ }^{34}$ Whei-Yang Kao W, Prockop DJ. Proline analogue $\overparen{D}^{2}$ removes fibroblasts from cultured mixed cell populations. Nature 1977;266:63.

${ }^{35}$ Valeriote FA, van Putten L. Proliferation dependent cytotoxicity of anti-cancer agents: a review. Cancer Res. $1975 ; 35: 2619$.

36 Bruce WR, Meeker BE, Valeriote FE. Comparison of the $\vec{\omega}$ sensitivity of normal haemopoietic and transplanted lymphoma colony-forming cells to chemotherapeuties agents administered in vivo. J Natl Can Inst 1966;37:233.

${ }^{37}$ Selby PJ, Thomas JM, Peckham MJ. A comparison of the ${ }^{+}$ chemosensitivity of a primary tumour and its metastases. using a human tumour xenograft. Eur J Cancer 1979;15:

${ }^{38}$ Berry RJ, Laing AH, Wells J. Fresh explant culture of human tumours in vitro and the assessment of sensitivity to cytotoxic chemotherapy. Br J Cancer. 1975;31:218.

${ }^{39}$ Bateman AE, Peckham MJ, Steel GG. Assays of drug sensitivity for cells from human tumours. $\mathrm{Br} J$ Cancer 1979;40:81.

40 Alberts DS, Salmon SE, Chen HSG, et al. In vitro clonogenic assay for predicting response of ovarian cancer to. chemotherapy. Lancet $1980 ; \mathrm{ii}: 340$.

${ }^{41}$ Kessel D, Hall TC, Robert BD. Uptake as a determinant of methotrexate response in mouse leukaemia. Science $1965 ; 150: 752$.

${ }^{42}$ Hall TC. Prediction of responses to therapy and mechan-ळి ism of resistance. Semin Oncol 1977;4:193.

${ }^{43}$ Bloomfield CD, Smith KA, Peterson BA, et al. In vitro glucocorticoid studies for predicting response to음 glucocorticoid therapy in adults with malignant lym- 3 phoma. Lancet $1980 ; \mathrm{i}: 952$.

44 Terenius L, Simonsson B, Nilsson K. Glucocorticoido receptors in chronic lymphocytic leukaemia. In: Bell PA, Borthwick NM, eds. Seventh tenovus workshop용 Glucocorticoid action and leukaemia. Cardiff: Alpha Omega Publishing Ltd, 1978:155.

${ }^{45}$ Schmidt TJ, Thomson EB. Glucocorticoid receptors and glutamine synthesis in leukaemic Sézary cells. Cancerô Res 1979;39:376.

${ }^{46}$ Lippman ME, Yarbro GSK, Leventhal BG. Glucocorti-o coid receptors in normal and leukaemic human leuco- $\supset$ cytes. In: Bell PA, Borthwick NM, eds. Seventh tenovus workshop. Glucocorticoid action and leukaemia. Cardiff:Alpha Omega Publishing Ltd, 1978:175.

${ }^{47}$ Koeffler HP, Golde DW, Lippman ME. Glucocorticoid sensitivity and receptors in cells of human myelogenous $N$ leukaemia lines. Cancer Res 1980;40:563.

48 McGuire WG. Steroid receptors in human breast cancer. Cancer Res 1978;38:4289.

49 Roper PR, Drewinko B. Cell survival following treatment with anti-tumour drugs (letter). Cancer Res 1979;39:을 1428.

so Roper PR, Drewinko B. Comparison of in vitro methods to determine drug-induced cell lethality. Cancer Res 1976; $36: 2182$.

31 Bhuyan BK, Loughman BE, Fraser TJ, Day KJ. Comparison of different methods of determining cell viability $\underset{\Phi}{\Phi}$ after exposure to cytotoxic compounds. Exp Cell Res 1976;97:275.

52 Hill BT, Whelan RDH, Rupniak HT, Rosholt MN. The value of an in vitro culture system for predicting drug sensitivities and their questionable clinical relevance 
Br J Cancer 1980;41(Suppl. IV):203.

53 Wells J, Berry RJ, Laing AH. The chemosensitivity of freshly explanted tumour cells of various origins as determined by clonal assay and 6-day growth in vitro and variation in chemosensitivity with subsequent subculturing. In: Dendy PP, ed. Human tumours in short term culture. London: Academic Press, 1976:158.

54 Puck TT, Marcus PI. A rapid method for viable cell titration and clone production with Hela cells in tissue culture. Proc Natl Acad Sci USA 1955;41:432.

55 Till JE, McCulloch EA. A direct measurement of the radiation sensitivity of normal mouse bone marrow cells. Radiation Res 1961;14:213.

s6 Park CH, Bergsagel DE, McCulloch EA. Mouse myeloma tumour stem cells: a primary cell culture assay. J Natl Cancer Inst 1971;46:411.

57 McAllister RM, Reed G. Colonial growth in agar of cells derived from neoplastic and non-neoplastic tissues of children. Paediatric Res 1968;2:356.

58 Altman AJ, Crussi FG, Rierden WJ, Backner RL. Growth of rhabdomyosarcoma colonies from pleural fluid. Cancer Res 1975;35:1809.

39 Courtenay VD, Smith IE, Peckham MJ, Steel GG. In vitro and in vivo radiosensitivity of human tumour cells obtained from a pancreatic carcinoma xenograft. Nature 1976;263:771.

0 Jones SE, Hamburger AW, Kim MB, Salmon SE. Development of a bioassay for putative human lymphoma stem cells. Blood 1979;53:294.

61 Buick RN, Stanisic TH, Fry SE, Salmon SE, Trent JM, Krasovich P. Development of an agar-methyl cellulose clonogenic assay for cells in transitional cell carcinoma of the human bladder. Cancer Res 1979;39:5051.

62 Buick RN, Fry SE, Salmon SE. Application of in vitro soft agar techniques for growth of tumour cells to the study of colon cancer. Cancer 1980;45:1238.

os Meyskens FL, Salmon SE. Inhibition of human melanoma colony formation by retinoids. Cancer Res 1979;39: 4055.

4 Buick RN, Till JE, McCulloch EA. Colony assay for proliferative blast cells circulating in myeloblastic leukaemia. Lancet $1977 ; \mathrm{i}: 862$.

${ }^{65}$ Macpherson IA. Soft agar techniques. In: Tissue culture methods and applications. Kruse PF, Patterson MK, eds. New York: Academic Press, 1973:267.
68 Gordon MY. Quantitation of haemopoietic cells from normal and leukaemic RFM mice using an in vivo colony assay. BrJ Cancer 1974;30:421.

${ }^{67} \mathrm{Lin} \mathrm{H}$, Stewart CC. Colony formation by mouse peritoneal exudate cells in vitro. Nature 1973;243:176.

${ }^{68}$ Stephens TC, Currie GA, Peacock JH. Repopulation of gamma-irradiated Lewis lung carcinoma by malignant cells and host macrophage progenitors. Br $J$ Cancer 1978;38:573.

9 Selby PJ, Thomas JM. Clonogenic cell survival curves for human melanoma xenografts using agar diffusion chamber and lung colony assays. Br J Cancer 1980;41 (Suppl. IV):150.

${ }^{70}$ Selby PJ, Steel GG. Clonogenic cell survival in cryopreserved human tumour cells. $\mathrm{Br} J$ Cancer 1981; (in press).

71 Ogawa M, Bergsagel DE, McCulloch EA. Cl.emotherapy of mouse myeloma: quantitative cell cultures predictive of response in vivo. Blood 1973;41:7.

${ }^{72}$ Marzotko F, Krafft W, Preibsch W, Schröder M. In vitro testing and clinical experience with 5 fluorouracil in gynaecologic cancer (German). Arch Geschwulstforsch $1976 ; 46: 140$.

${ }^{73}$ Shorthouse AJ, Peckham MJ, Smyth JF, Steel GG. The therapeutic response of bronchial carcinoma xenografts: a direct patient-xenograft comparison. Br $J$ Cancer $1980 ; 41$ (Suppl. IV):142.

${ }^{74}$ Rupniak HT, Hill BT. The poor cloning ability in agar of human tumour cells from biopsies of primary tumours. Cell Biology International Reports 1980;4:479.

${ }^{75}$ Povlsen CO. Aspects of treatment of human cancer. In: The nude mouse in experimental and clinical research. Fogh J, Giovanella BC, eds. New York: Academic Press, 1978:450.

78 Bailey MJ, Raghavan D, Jones AC, et al. Limitations of the human tumour xenograft system in individual patient drug sensitivity testing. Submitted for publication 1981 .

Requests for reprints to: Dr Peter Selby, Department of Medicine, Princess Margaret Hospital, 500 Sherbourne Street, Toronto, Canada M4X 1K9. 